\title{
IMPLEMENTASI MODEL FULL DAY SCHOOL DALAM MEMBENTUK KARAKTER DAN KEDISIPLINAN SISWA DI SD AISYIYAH 1 MATARAM
}

\author{
Mardiyah Hayati ${ }^{1}$, Mappanyompa ${ }^{2}$ \\ 1,Program Studi PGMI, ${ }^{2}$ Program Studi KPI, Universitas Muhammadiyah Mataram, Indonesia \\ Mardiyahhayai4@gmail.com ${ }^{1}$, myompakaltim@gmai.com $^{2}$
}

\begin{tabular}{l} 
INFO ARTIKEL \\
\hline Riwayat Artikel: \\
Diterima: $02-01-2020$ \\
Disetujui: $30-04-2020$ \\
\end{tabular}

Kata Kunci:

Pendidikan Agama Islam,

Full Day school,

Pendidikan karakter

Keywords:

Islamic Studies,

Full Day School,

Character Education

\begin{abstract}
ABSTRAK
Abstrak: Pendidikan Agama Islam merupakan upaya sadar dan terencana dalam menyiapkan peserta didik untuk mengenal,memahami, menghayati, mengimani, bertakwa dan berakhlak mulia. Tujuan penelitian ini adalah untuk mengetahui bagaimana implementasi Pendidikan Agama Islam Pada Model Full Day School Dalam Membentuk Karakter Dan Kedisiplinan Siswa di SD 'Aisyiyah 1 Mataram, proses pembelajaran, kendala dan solusinya. Penelitian ini merupakan penelitian lapangan (field research) yang dilakukan di SD 'Aisyiyah 1 Mataram. Adapun jenis pendekatan yang digunakan adalah bersifat kualitatif yang menghasilkan data deskriptif berupa kata-kata tertulis maupun lisan dari orang-orang yang diamati. Metode yang digunakan dalam penelitian ini yaitu : wawancara, metode ini digunakan untuk memperoleh data tentang bagaimana implementasi Pendidikan Agama Islam pada model full day school ,apa kendalanya dalam pembentukan karakter di SD 'Aisyiyah 1 Mataram. Observasi, Metode ini untuk melihat langsung terkait proses Implementasi model pembelajaran full day school di SD 'Aisyiyah 1 Mataram. Dokumentasi, metode ini untuk memperoleh data tentang gambaran umum sekolah,sejarah berdirinya,keadaan guru dan siswa. Analisis data. Dalam menganalisis data peneliti menggunakan diskriptif kualitatif.
\end{abstract}

Abstract: Islamic education is a conscious and planned effort in preparing learners to know, understand, internalize, immoral, cautious and noble. The purpose of this research is to know how to implement Islamic education on the Model Full Day School in forming character and discipline students in SD 'Aisyiyah 1 Mataram, learning process, constraints and solutions. This research is a field research conducted at SD 'Aisyiyah 1 Mataram. The kind of approach used is qualitative that generates descriptive data in the form of written or spoken words from those observed. The methods used in this study are: Interviews, this method is used to obtain data on how to implement Islamic education on the full day school model, what is the control in character building in $S D$ ' Aisyiyah 1 Mataram. Observation, this method to see directly related to the process of implementing a full day school learning model in SD ' Aisyiyah 1 Mataram. Documentation, this method to obtain data about the overview of the school, the history of its establishment, the state of teachers and students. Data analysis. In analyzing the researcher's data using qualitative diskriptif.

\section{A. LATAR BELAKANG}

Remaja Masjid Globalisasi merupakan fenomena yang muncul dan banyak dibicarakan oleh masyarakat di era 1980-an. seiring berkembangnya zaman yang dipengaruhi oleh globalisasi tersebut, menuntut masyarakat untuk menguasai ilmu pengetahuan dan teknologi serta keterampilan yang membuatnya berkembang mengikuti arah perkembangan zaman. Era globalisasi banyak memberikan dampak bagi kehidupan sosial baik berupa dampak negatif maupun dampak positif, terutama dikalangan anak didik. $^{1}$

${ }^{1}$ Journal naskah publikasih skripsi. Pdf didownload 10/01/2019 jam 10.30 Wita
Kemajuan dunia yang berjalan dengan sangat cepat ini harus direspon secara serius agar anak didik siap menghadapi gempuran dunia yang demikian dahsyat. Karena dari banyaknya masalah yang muncul kadang membuat anak didik tidak mampu untuk mengontrol dirinya, bahkan hadirnya berbagai macam kesibukan membuat anak didik lupa akan kewajibanya menjadi peserta didik. $^{2}$

Tujuan utama seseorang belajar adalah untuk menggali, mencari dan mendapatkan ilmu terlebih lagi mengimplementasikanya dengan menunjukan dalam pembentukan karakter dan kedisiplinanya. Karena hadirnya pendidikan

2 Jamal Ma'murasmani, Full Day School ( Yokyakarta: Ar-Ruzz Media, 2017) hlm 7 
merupakan salah satu upaya untuk mengantarkan anak didik menuju kepada proses kedewasaan dalam berbagai aspek. Sesuai dengan undangundang nomor 20 pasal 3 tahun 2003 tentang dasar, fungsi, dan tujuan sistem pendidikan nasional yang menyatakan bahwa: ${ }^{3}$

Pendidikan nasional berfungsi mengembangkan kemampuan dan membentuk watak serta peradaban bangsa yang bermartabat dalam rangka mencerdaskan kehidupan bangsa, bertujuan untuk berkembangnya potensi peserta didik agar menjadi manusia yang beriman dan bertakwa kepada Tuhan Yang Maha Esa, berakhlak mulia, sehat, berilmu, cakap kreatif, mandiri, dan menjadi warga negara yang demokratis serta bertanggung jawab. ${ }^{4}$

Pendidikan harus disingkronkan dengan agama Islam agar mampu membentuk kepribadian dan kedisiplinan yang sifatnya hakiki dalam kehidupan. Maka adanya pendidikan agama Islam adalah upaya sadar dan terencana dalam menyiapkan peserta didik untuk mengenal, memahami, menghayati, hingga mengimani, bertakwa dan berakhlak mulia dalam mengamalkan ajaran agama Islam dari sumber utamanya kitab Al-Qur'an hadits, melalui kegiatan bimbingan, pengajaran, latihan, serta penggunaan pengalaman. Disertai dengan tuntunan untuk menghormati penganut agama lain dalam hubungannya, dalam kerukunan antar umat beragama, dalam masyarakat hingga terwujud kesatuan dan persatuan bangsa. 5

Dari hasil observasi yang dilakukan di SD 'Aisyiyah 1 Mataram penulis menemukan permasalah-permasalah yang sering muncul pada diri siswa di antaranya adalah banyak siswa/pelajar sekarang yang tidak memanfaatkan waktu luang untuk hal-hal yang bermanfaat, misalnya bermain, menonton televisi, bermain play station, mengganggu temanya, lempar buku kesana-kemari, tidak disiplin dan lain sebagainya, bukan digunakan untuk investasi masa depan, seperti mengaji, belajar, mengikuti kegiatan ekstrakurikuler, dan kegiatan positif lainya.

Dalam konteks ini full day school hadir sebagai solusi alternatif yang menjadikan sekolah sebagai wadah untuk meningkatkan kualitas pendidikan secara optimal demi terciptanya masa depan bangsa yang berkualitas tinggi. Karena full day school adalah sekolah sepanjang hari atau proses belajar mengajar yang diberlakukan dari

\footnotetext{
${ }^{3}$ Permediknas, "SI DAN SKL" (Jakarta: Sinar Grafika, 2006), $\operatorname{hlm} 2$

${ }^{4}$ Abdul Majid dan Dian Andayani, pendidikan Agama Islam Berbasis Kompetensi (Bandung: PT Remaja Rosdakarya, 2006), hlm 130

${ }^{5}$ Nurlaila S.ag, guru pendidikan agama islam SD 'Aisyiyah 1 Mataram
}

pagi hari sampai sore hari, mulai pukul 06.4515.30 WIB, dengan durasi istirahat setiap dua jam sekali.

Oleh karena itu sebagai sebuah terobosan penting, full day school diharapkan mampu membongkar mitos bahwa anak-anak Indonesia tidak mampu belajar keras sebagaimana bangsabangsa maju lainya. Dengan full day school, anakanak Indonesia ditempa dengan pendidikan dinamis dan kreatif dalam rangka mampu membentuk karaktek dan kedisiplinan dalam diri siswa sesuai dengan kegiatan harian. SD 'Aisyiyah selama ini menjalankan model full day school.

\section{B. METODE PENELITIAN}

Permaslahan Mitra Jenis penelitian yang digunakan pada penelitian ini adalah kualitatif. Penelitian kualitatif adalah penelitian yang bermaksud untuk memahami fenomena tentang apa yang dialami oleh subjek penelitian misalnya perilaku, persepsi, motivasi, tindakan dan lain-lain. Secara holistik dan dengan deskripsi dalam bentuk kata-kata dan bahasa pada suatu konteks khusus yang alamiah dan dengan memanfaatkan berbagai metode ilmiah. ${ }^{6}$

Penelitian kualitatif memiliki beberapa jenis pendekatan, salah satunya adalah pendekatan deskriptif yaitu sebuah pendekatan yang mengumpulkan data berupa kata-kata, gambar, dan bukan angka. Bertujuan melakukan analisis dan menyajikan fakta secara sistematik sehingga lebih mudah difahami dan disimpulkan. ${ }^{7}$

Menurut Bogdan and Biklen (dalam Sugiyono), bahwa ada beberapa karakteristik penelitian kualitatif yaitu: (1) dilakukan pada kondisi alamiah, (sebagai lawannya adalah eksperimen), langsung ke sumber data dan peneliti adalah instrumen kunci. (2) penelitian lebih bersifat deskriptif. Data yang terkumpul berbentuk kata-kata atau gambar, sehingga tidak menekankan pada angka. (3) penelitian kualitatif lebih menekankan pada proses daripada produk atau outcome. (4) penelitian kualitatif lebih melakukan analisis data secara induktif. (5) penelitian kualitatif lebih menekankan makna (data dibalik yang teramati). ${ }^{8}$

Dari uraian di atas, maka dapat disimpulkan bahwa penelitian ini menggunakan metode penelitian kualitatif dengan pendekatan deskriptif yaitu untuk mengumpulkan kata-kata, gambar, dan bukan angka, berusaha menggambarakan secara

${ }^{6}$ Lexi J. Moleong, Metode Penelitian Kualitatif (Bandung: PT REMAJA ROSDAKARYA, 2013) hlm 6

${ }^{7}$ Ibid. hlm 11

${ }^{8}$ Saifudin Azwar, Metode Penelitian(Yokyakarta: PUSTAKA PELAJAR Yokyakarta, 2015) hlm 6 
sistematik dan akurat fakta dan karakteristik mengenai populasi atau mengenai bidang tertentu.

\section{Lokasi Penelitian}

Lokasi penelitian adalah tempat di mana penelitian akan dilakukan, beserta jalan dan kotanya. Dalam penelitian ini peneliti mengambil lokasi di SD 'Aisyiyah 1 Mataram Jl. Anyelirn 2-4 Mataram, Gomong, Kec. Selaparang, kota Mataram.

\section{Metode Pengumpulan Data/Instrumen Penelitian}

Terdapat dua hal utama yang mempengaruhi kualitas data hasil penelitian, yaitu, kualitas instrumen pendidikan dan kualitas pengumpulan data. Dalam penelitian kualitatif, yang menjadi instrumen atau alat penelitian adalah peneliti itu sendiri.Oleh karena itu peneliti sebagai instrumen juga harus "divalidasi" seberapa jauh peneliti kualitatif siap melakukan penelitian yang selanjutnya terjun ke lapangan.Validasi terhadap peneliti sebagai instrumen meliputi validasi terhadap pemahaman metode penelitian kualitatif, penguasaan wawasan terhadap bidang yang diteliti, kesiapan peneliti untuk memasuki obyek peneliti, baik akademik maupun logistiknya. ${ }^{9}$

Berkaitan dengan hal tersebut, maka teknik yang digunakan dalam pengumpulan data yang relevan permasalahan penelitian ini adalah:

1) Wawancara

Wawancara adalah percakapan dengan maksud tertentu oleh dua pihak, yaitu pewancara (interview) sebagai pengaju/pemberi pertanyaan dan yang diwawancarai (interviewee) sebagai pemberi jawaban atas pertanyaan itu.

Wawancara atau Interview terdiri atas beberapa jenis sebagai berikut:

a. Wawancara pembicaraan Informal, jenis wawancara ini pertanyaan yang diajukan sangat tergantung pada pewawancara itu sendiri, jadi bergantung spontanitasnya dalam mengajukan pertanyaan yang diwawancarai.

b. Pendekatan Menggunakan Petunjuk Umum Wawancara, jenis wawancara ini mengharuskan pewawancara membuat kerangka dan garis besar pokok-pokok pertanyaan dalam wawancara, tetapi tidak harus dipertanyakan secara berurutan.

c. Wawancara Baku Terbuka, Jenis wawancara ini menggunakan seperangkat pertanyaan baku. Urutan pertanyaan, kata-katanya dan cara penyajiannya sama untuk setiap responden. d. Wawancara Terstruktur dan Wawancara tidak Terstruktur, jenis wawancara ini adalah wawancara yang pewawancaranya menetapkan sendiri masalah dan pertanyaan-pertanyaan yang akan diajukan.

Wawancara yang digunakan dalam penelitian ini adalah wawancara terstruktur dan tidak terstruktur. Wawancara ini memakai katakata pertanyaan yang dapat di ubah saat wawancara, dengan penyesuain kebutuhan dan situasi wawancara, dengan cacatan tidak menyimpang dari informasi yang dibutuhkan untuk penelitian ini.

2) Observasi

Observasi adalah suatu proses yang kompleks, suatu proses yang tersusun dari berbagai proses biologis dan psikologis. Dua di antaranya yang terpenting adalah proses-proses pengamatan dan ingatan.

Secara garis besarnya observasi dapat dilakukan sebagai berikut:

a. Observasi Berperan Serta (participant Observation), dalam observasi ini, peneliti terlibat dengan kegiatan sehari-hari orang yang sedang diamati atau yang digunakan sebagai sumber data penelitian. ${ }^{10}$

b. Observasi Nonpartisipan, dalam observasi ini, peneliti terlibat langsung dengan aktivitas orang-orang yang sedang diamati, maka dalam observasi nonpartisipan peneiiti tidak terlibat dan hanya sebagai pengamati independen.

Dalam penelitian ini, akan digunakan teknik obsevasi yang berperan serta (participant Observation) di mana peneliti terlibat dengan kegiatan sehari-hari dengan siswa yang sedang diamati atau yang digunakan sebagai sumber data penelitian. Dengan observasi partisipan ini, maka data yang diperoleh akan lebih lengkap, tajam dan sampai mengetahui pada tingkat makna dari setiap perilaku yang tampak.

3) Dokumentasi

Dokumentasi merupakan teknik pengumpulan data ketiga yang dilakukan oleh peneliti untuk melengkapi data yang dibutuhkan dalam penelitian sebagaimana teori yang dikatakan berikut ini: "dokumentasi merupakan catatan peristiwa yang sudah berlalu". Dokumentasi bisa terbentuk tulisan (surat, catatan harian, sejarah kehidupan, cerita, biografi) gambar (foto) atau karya-karya monumental dari seseorang. ${ }^{11}$

Berdasarkan teori di atas dapat disimpulkan bahwa dalam teknik dokumentasi ini peneliti akan 
menggunakan foto, catatan tentang kegiatan implementasi pendidikan pada model full day school dalam membentuk karakter dan kedisiplinan siswa.

\section{Teknis dan Sumber Data}

Sumber data merupakan narasumber, responden dan informan dalam memberikan data kepada peneliti dalam proses penelitian. Dalam penelitian ini peneliti memilih beberapa sumber data yang berbeda di lokasi penelitian yaitu meliputi.

1. Data primer, dalam penelitian ini dari subjek dan objek penelitian dengan menggunakan daftar pertanyaan atau wawancara dan obsevasi. Adapaun yang diwawancara yaitu guru kelas III dan beberapa siswa yang bermasalah dalam pembentukan karakter dan kedisiplinanya di sekolah dan melakukan obsevasi terhadap pola penerapan full day school di kelas III di SD 'Aisyiyah 1 Mataram.

2. Data sekunder, dalam penelitian ini berupa dokumentasi tertulis berupa foto proses penerapan Full Day School dan catatan perilaku siswa yang berkaitan dengan penelitian yang berada di SD 'Aisyiyah 1 Mataram secara umum di sekolah. Serta hal-hal yang didapatkan dalam penelitian secara tidak langsung.

\section{Teknik Analisis Data}

Analisis atau penafsiran data adalah proses mencari, menyusun dan mengatur secara sistematis catatan temuan penelitian melalui pengamatan dan wawancara dan lainya untuk meningkatkan pemahaman peneliti tentang fokus yang dikaji dan menjadikan sebagian temuan orang lain, mengedit, mengklasifikasi, mereduksi dan menyajikan. ${ }^{12}$

Setelah data diperoleh dan dikumpulkan maka dilakukan analisis data dengan cara kualitatif berdasarkan berdasarkan model Miles and Huberman. Di mana data yang diperoleh di lapangan akan direduksi, disajikan dan ditarik kesimpulan. Ada tiga (3) tahapan dalam menganalisis data kualitatif yaitu: ${ }^{13}$

1. Reduksi Data

Merupakan proses berfikir sensitif yang memerlukan kecerdasan dan keluasan dan kedalaman wawasan yang tinggi. Sehingga data yang diperoleh oleh peneliti di lapangan yang jumlahnya begitu banyak harus dicatat secara teliti dan rinci.

\footnotetext{
${ }^{12}$ Emzir, Metodologi penelitian Kualitatif Analisis (Jakarta: Raja Grafindo Persada, 2012) hlm 37

${ }^{13}$ Tohrin, Metode Penelitian Kualitatif dalam Pendidikan dan Bimbingan Konseling(Depok: PT RAJAGRAFINDO, 2012) hlm 141
}

\section{Penyajian Data}

Merupakan sekumpulan informasi tersusun yang memberikan kemungkinan adanya penarikan kesimpulan.Setelah data direduksi maka langkah selanjutnya adalah mendisplay data.Dalam penelitian kualitatif, penyajian data bisa dilakukan dalam bentuk uraian singkat, bagan, hubungan antar kategori, flowcharl dan sejenisnya.

\section{Menarik Kesimpulan}

Menarik kesimpulan menurut Miles dan Hubermanadalah penarikan kesimpulan dan verifikasi. Kesimpulan awal yang dikemukakan masih bersifat sementara dan akan berubah bila tidak ditemukan bukti-bukti yang kuat yang mendukung pada tahap pengumpulan data berikutnya. Tetapi apabila kesimpulan yang dikemukakan pada tahap awal, didukungdengan bukti yang valid dan konsisten saat peneliti kembali ke lapangan mengumpulkan data, maka kesimpulanyang dikemukakan merupakan kesimpulan yang kredibel. ${ }^{14}$

\section{HASIL DAN PEMBAHASAN}

1. Implementasi Pendidikan Agama Islam pada Model Full Day School dalam Membentuk Karakter dan Kedisiplinan Siswa SD `Aisyiyah 1 Mataram.

SD 'Aisyiyah 1 Mataram menyelenggarakan model full day school, di mana penerapan pendidikan agama Islam dalam model full day school ini dilakukan agar mampu membentuk karakter dan kedisiplinan yang dimiliki oleh para siswa. Bukan hanya itu saja melainkan untuk meningkatkan potensi spiritual dan membentuk peserta didik agar menjadi manusia yang beriman dan bertaqwa kepada Tuhan Yang Maha Esa dan berakhlak mulia. Peningkatan potensi spritual mencakup pengenalan, pemahaman, dan penanaman nilai keagamaan, serta pengamalan nilai-nilai tersebut dalam kehidupan individual ataupun kolektif kemasyarakatan. Peningkatan potensi spritual tersebut pada akhirnya bertujuan pada optimalisasi berbagai potensi yang dimiliki manusia yang aktualisasinya mencerminkan harkat dan martabat sebagai makhluk Tuhan.

Seperti yang dijelaskan oleh guru pendidikan agama Islam yakni Nurlaila S.Ag beliau mengutarakan.

SD 'Aisyiyah 1 Mataram menerapkan ekstrakurikuler, salah satunya adalah ekstra agama. Hal ini dilakukan karena dilihat waktu 
paginya tidak cukup untuk membentuk karakter dan kedisiplinan siswa, maka guru-guru menerapkan ekstra agama untuk menunjang dari pada pedoman hidup yakni Al-qur'an dan assunnah. Jangan sampai anak-anak tidak mengetahui apa yang menjadi pedoman hidupnya, apalagi hanya mengetahui isinya tetapi tidak mengetahui bunyinya. ${ }^{15}$

Dari hasil wawancara yang dilakukan Selanjutnya dalam kegiatan rutin setiap hari seperti kegiatan do'a bersama sebelum memulai pembelajaran. Sebelum pembelajaran dimulai peserta didik seluruhnya berbaris di luar kelas sambil berdo'a dan menghafal hadits yang dibimbing oleh guru maupun dipimpin oleh temannya yang bertugas.

Adapun kegiatan harian yang diselenggarakan di SD 'Aisyiyah 1 Mataram dari hari Senin sampai hari jumat, yaitu sebagai berikut: 1). Pukul 07.30-09.00: pelajaran agama (juz amma) 2). Pukul 09.00-09.30: istrahat bermain

3). Pulkul 09.30-11.30: program kegiatan belajar

4). Pukul 11.30-12.00: makan siang

5). Pukul 12.00-12.30:shalat dhuhur

6). Pukul 12.30-13.30: istrahat

7). Pukul 13.30-14.00: program kegiatan belajar

8). Pukul 14.00-15.00: ekstrakurikuler

Diantara implementasi pendidikan agama

Islam yaitu pembentukan karakter dan kedisiplinan pada model full day school maka sekolah juga menambah mata pelajaran tahfiz dan kegiatan ekstrakurikuler agama yaitu;

1). Pelajaran Tahfiz, pelajaran tahfiz ini dilakukan dua kali dalam satu pekan yaitu pada hari Selasa dan Rabu. Hal ini dilakukan pada pagi hari mulai dari jam 07:30 - 08.30. Adapun target hafalan mulai dari juz 30 .

2). Ceramah agama, kegiatan ceramah dilakukan pada hari Jum'at. Ceramah akan bergilir dengan sholat dhuha setiap pekan. dan dilaksanakan mulai dari jam 07:30-08.30 yang disampaikan bergantian oleh siswa yang sudah di tunjuk sebelumnya,

3). Sholat dhuha, dikerjakan pada hari jum'at dan dilakukan dg imam secara bergiliran sesuai yang sudah dijadwalkan. Demikian juga dengan kultum/ceramah agama, setelah melakukan sholat dhuha kemudian dilanjutkan dengan dzikir bersama. Sholat dhuha dikerjakan mulai dari jam 07:30:08:30,

4). Sholat berjamaah dhuhur dikerjakan setiap hari pada hari aktif sekolah. Sholat berjamaah dikerjakan bersama-sama mulai dari kelas I sampai kelas VI yang bertempat di Aula bersama TK 'Aisyiyah 2 Mataram.

5). Hafalan hadits, dilakukan didalam kelas maupun diluar kelas, hafalan hadits dilakukan pada hari jum'at setelah melakukan sholat dhuha sekitar jam 08:30-09:00. Adapun hadits yang dihafalkan ialah hadits yang sudah programkan oleh sekolah. Hal ini dilakukan agar anak-anak membiasakan diri untuk menumbuhkan rasa cinta terhadap Al-qur'an dan As-sunnah, lebih-lebih taat terhadap perintah Allah SWT, karena adanya Al-Qur'an dan As-Sunnah bukan hanya untuk dihafalkan melainkan untuk diimplementasikan dalam kehidupannya.

Sehingga dari banyaknya kegiatan yang terdapat pada model full day school akan mempermudah dalam membentuk karakter dan kedisiplinan siswa/siswi sehingga tidak membuat orang tua siswa khawatir, bahkan orang tua siswa/siswipun merasa bahagia karena anakanaknya lebih aman di sekolah.

Implementasi pendidikan agama Islam pada model full day school sangat berpengaruh bagi para siswa karena bisa saja ketika anak-anak tidak mendapatkan ilmu agama pada lini keluraganya kemudian mereka mendapatkan di sekolah.

\section{Dampak implementasi pendidikan agama Islam pada model full day school dalam membentuk karakter dan kedisiplinan siswa SD 'Aisyiyah 1 Mataram}

Pembentukan karakter dan kedisiplinan siswa merupakan tujuan pendidikan. Secara garis besar pembentukan karakter diimplementasikan dalam setiap kegiatan pembelajarannya di program full day school, terutama pada pendidikan agama Islam. Dari beberapa hasil wawancara yang dilakukan. Berikut salah satu hasil wawancara mengenai dampak implementasi pendidikan agama Islam pada model full day school.

Anak-anak mempunyai kegiatan yang positif dalam hal ini di koordinir oleh sekolah baik dalam membimbingnya shalat, membaca al-qur'an, menghafal hadits maupun dalam hal berperilaku. Hal ini dilakukan karena melihat ketika ana-anak pulang ke rumah masing-masing lebih sibuk dengan geajetnya dibandingkan mengerjakan halhal yang bermanfaat, maka hadirnya full day school ini agar mampu memberi dampak positif pada diri siswa. Sehingga guru-gurupun berusaha membimbingnya dengan semaksimal mungkin. 16 
Dari hasil wawancara yang dilakukan dengan guru pendidikan agama Islam Kegiatan pembentukan karakter dilakukan melalui kedisiplinan, yang terwujud dengan 3 metode yakni kedisiplinan dalam pembiasaan, keteladanan dan penguatan yaitu sebagai berikut:

a. Pembiasaan; Kebiasaan akan membentuk karakter, karakter akan membentuk perilaku. Kalimat tersebut adalah pedoman yang dianut setiap orang untuk menilai perilaku seseorang. Dengan kata lain perilaku seseorang terbentuk dari karakternya, dan karakter terbentuk dari kebiasaan yang dijalani. Rumus kehidupan mendisiplinkan pembiasaan inilah yang melatarbelakangi diterapkannya program full dayschool di SD 'Aisyiyah 1 Mataram agar pihak sekolah bisa menerapkannya dalam kehidupan sehari-hari. Pembiasaan menjadi metode pembelajaran strategis untuk memantapkan pembentukan karakter dan kepribadian siswa yang berakhlak karimah. Proses pembelajaran tidak berhenti pada kegiatan belajar mengajar di kelas, akan tetapi berlanjut pada proses pembiasaan dan kegiatan rutin sehari-hari, seperti pembiasaan bertanggung jawab, pembiasaan salam, adab makan, adab tidur, adab bergaul, pembiasaan shadaqah, budaya bersih lingkungan dan sebagainya. Pembentukan karakter erat hubungannya dengan pembentukan perilaku, karena karakter seseorang diukur dari bagaimana orang tersebut berperilaku. Dalam pembentukan karakter, perilaku tersebut dibentuk melalui urutan-urutan upaya untuk mendekati perilaku yang diinginkan, masing-masing dimungkinkan dengan secara selektif menguatkan responrespon tertentu dan bukan lainnya. Dengan cara demikian secara bertahap, perilaku dibawa mendekati pola yang diinginkan.

b. Keteladanan; Selain mengajar dan mendidik, guru juga berperan sebagai model atau contoh bagi anak didik. Oleh karena itu tingkah laku guru sebagai teladan akan mengubah perilaku siswa karena guru adalah penuntun siswa. Guru yang berperilaku baik akan dihormati dan disegani siswa, jadi guru harus mendidik dirinya sendiri terlebih dahulu dalam perkataan dan perbuatan sebelum mendidik orang lain. Tutur kata guru di sekolah dapat memberikan pengaruh yang positif maupun negatif terhadap siswa. Tindakan guru juga mempengaruhi perilaku dan tindakan siswa. Anak usia memasuki sekolah dasar berada pada tahap imitasi, individu yang menjadi model disini adalah orang-orang dewasa yang dekat dengan anak, bisa anggota keluarga dan guru di sekolah.
Untuk itu selain membimbing dan mengajarkan anak tentang nilai-nilai karakter yang baik, guru dan orang tua juga dituntut untuk menjadi model yang baik bagi anak didiknya.

c. Penguatan; Penguat disini merupakan stimulus agar anak mau untuk mengulangi lagi perilakuperilaku baik yang berhubungan dengan pembentukan karakter. Dalam hal pembentukan, agar perilaku yang diinginkan tersebut terjadi lagi berulang-ulang diperlukan penguat. memberikan contoh mengenai penguat positif dimisalkan bahwa "seorang anak melakukan suatu perbuatan dan mendapatkan pujian guru, maka si anak akan melakukan perbuatan yang sama dan ingin mendapat pujian kembali". Penguat positif disini yaitu pujian dari guru, penguat positif berupa stimulus yang menyenangkan.

Guru berharap ketika 3 metode itu diterapkan mampu membentuk karakter dan kedisiplinan yang dimiliki siswa.

Terkait dampak yang dirasakan oleh siswa di sekolah, seperti hasil wawancara di atas bahwa siswa yang bersangkutan mendapatkan perubahan ketika mengimplementasikan pendidikan agama Islam pada model full day school.

Tampak jelas dari penerapan model full day school mampu membentuk karakter dan kedisiplinan siswa, terlebih lagi mampu mengembangkan bebarapa potensi, diantaranya ialah mampu menghafal hadits, Al-Quran dan ceramah, sehinnga dengan kegiatan-kegiatan tersebut mampu meningkatkan kepercayaan diri siswa.

\section{Kendala dalam implementasi pendidikan agama Islam pada model full day school dalam membentuk karakter dan kedisiplinan siswa kelas SD 'Aisyiyah 1 Mataram}

Setiap manusia memang tidak menyukai sesuatu kegiatan yang terlalu lama, lebih-lebih satu hari penuh di sekolah walaupun banyak teman bermain akan tetapi tidak menutup kemungkinan akan ada rasa jenuh. Berikut hasil wawancara peneliti dengan ibu Nurlaila terkait masalah siswa yang mempunyai kendala dalam mengimplementasikan pendidikan agama Islam pada model full day school.

Kendala yang terlihat pada penerapan model full day school lebih kepada siswa karena dari beberapa siswa ada yang merasa jenuh ketika terlalu lama di sekolah dan malas akan menerima pelajaran. Kalaupun dari sisi orang tuanya pun tidak terlihat ada kendala baik dari sisi ekonomi 
maupun kepercayaan yang diberikan terhadap guru untuk menjaga anak-anaknya. ${ }^{17}$

Dari hasil wawancara di atas, maka Implementasi program full day school perlu memperhatikan kenyamanan siswa dalam melaksanakan program pembelajaran maupun kegiatan-kegiatan yang terdapat di sekolah dan kenyamanan orangtua/ masyarakat dalam menyerahkan kepercayaan sepenuhnya pada pihak sekolah untuk memaksimalkan potensi dan mengefetifkan waktunya lebih-lebih ilmu agama yang akan menunjang tercapainya pembentukan karakter dan kedisiplinan siswa.

Maka dari itu pihak sekolah harus memaksimalkan seluruh potensinya demi tercapainya tujuan pendidikan, maka pemenuhan dari pada sarana dan prasarana sangat penting untuk menunjang keberhasilan dalam pembentukan karakter dan kedisiplinan siswa dan agar siswa tidak merasa bosan sehingga mengganggap dunianya hanya seputar lingkungan sekolah saja.

\section{SIMPULAN DAN SARAN}

\section{a. Simpulan}

Berdasarkan hasil penelitian dari pembahasan "Implementasi Pendidikan Agama Islam Pada Model Full Day School Dalam Membentuk Karakter dan Kedisiplinan Siswa Kelas III SD 'Aisyiyah 1 Mataram". Peneliti menyimpulkan bahwa, implementasi pendidikan agama Islam pada model full day school melahirkan banyak kegiatan, diantaranya ialah penerapan ekstrakurikuler yang salah satunya adalah ekstra agama. Ekstra agama merupakan eksra wajib yang diikuti oleh siswa/siswi yaitu tahfiz Al Qur'an, sholat dhuha, ceramah, sholat berjamaah dan menghafal hadits.

Dampak yang dirasakan oleh siswa/siswi dari implementasi Pendidikan Agama Islam pada model full day school adalah membuat siswa/siswi lebih disiplin, mampu membentuk karakternya, sehingga siswa/siswi juga mampu menggali potensi yang terdapat pada diri masing-masing dan menjadi anak-anak yang bermanfaat bagi bangsa dan negara.

Adapun potensi yang terdapat pada diri siswa yaitu:
a. Menghafalkan Al Quran
b. Menghafal hadits
c. Ceramah agama

Kendala pada setiap penerapan akan tetap dirasakan diantaranya kebosanan, oleh karena itu sekolah harus memaksimalkan seluruh potensi yang dimiliki agar sebisa mungkin bisa mencapai target dari tujuan pendidikan tersebut.

\section{b. Saran}

Berdasarkan hasil kesimpulan diatas maka dapat menjadi bahan pertimbangan bagi

1. Kepala sekolah

Sekolah sebagai tempat pelaksanaan kegiatan belajar mengajar hendaknya menciptakan suasana yang nyaman dan kondusif untuk membantu proses belajar mengajar, ksususnya dalam pembentukan karakter dan kedisiplinan siswa. Hendaknya kepala sekolah lebih teliti lagi dalam memperhatikan kenyamanan yang dirasakan oleh siswa, maka dari itu pihak sekolah hendaknya menyediakan lingkungan khusus sebagai alternatife untuk tempat bermain siswa agar siswa senantiasa semangat mengikuti pembelajaran dan kegiatan-kegiatan yang ada di sekolah.

2. Guru-guru

Kepada para guru khendaknya berkontribusi dalam membantu kepala sekolah agar senantiasa mengembangkan kreativitas dalam proses pembelajaran maupun dalam kegiatan-kegiatan demi memperoleh kemajuan, meningkatkan keefektifan, membentuk karakter dan kedisiplinan yang terdapat pada diri siswa.

\section{Kepada Para Peneliti}

Kepada para peneliti, sebagai referensi dan merancang penelitian sejenis tentang Implementasi Pendidikan Agama Islam Pada Model Full Day School Dalam Membentuk Karakter Dan Kedisiplinan Siswa SD 'Aisyiyah 1 Mataram.

\section{DAFTAR RUJUKAN}

Agung. 2012. Full Day school. Majalah Percikan Iman.

Alim, Muhammad. 2011. Pendidikan Agama Islam. Bandung: PT Remaja

Al-Qur'an Penerjemah. 2017. Bogor: Halim

Aminuddin. 2005. Pendidikan Agama Islam. Bogor: Ghalia Indonesia

Azwar Saifudin. 2015. Metode Penelitian. Yokyakarta: PUSTAKA PELAJAR

Emzir. 2012. Metodologi penelitian Kualitatif Analisis. Jakarta: Raja Grafindo Persada.

Fatchul Mu'in. 2011. Pendidikan Karakter Konstruksi teoritik dan Praktik. Yokyakarta: Ar Ruzz Media 
8 Ibtida'íy : Jurnal Prodi PGMI | Vol. 5, No. 1, April 2020, hal. 1-8

Gunawan, Heri. 2012. Pendidikan Karakter Konsep dan Imlementasi. Bandung: Alfabeta

Hasan, Nor. 2016. Full Day School (Model Alternatif PembelajaranBahasa Asing). Jurnal Pendidkan

Lickona Thomas 2014. Pendidikan Karakter. Bandung: Katalog dala Terbitan

Ma'murasmani Jamal. 2017. Full Day Cchool. Yokyakarta: Ar-Ruzz Media

Majid Abdul dan Andayani Dian. 2016. Pendidikan Agama Islam Berbasis Kompetensi. Bandung: PT Remaja Rosdakarya

Marzuki. 2015. Pendidikan Karakter Islam. Jakarta: Bumi Aksara

Moleong, Lexi. 2013 Metode Penelitian Kualitatif. Bandung: PT REMAJA ROSDAKARYA

Mulyasa, E. 2013. Kurikulum Berbasis Kompetensi: Konsep, karakteristik, dan Implementasi. Bandung: PT REMAJA ROSDAKARYA.

Permediknas. 2016. "SI DAN SKL" Jakarta: Sinar Grafika

Samani Muchlas. 2011. Penelitian Karakter. Bandung: PT Remaja Rosdakarya

Sugiyono. 2015. Memahami Penelitian Kualitatif. Bandung: ALFABETA

Sugiyono. 2016. Metode Penelitian Kuantitatif Kualitatif dan R\&D. Bandung: ALFABETA

Sugiyono. 2017. Metode Peneitian Pendidikan. Bandung: ALFABETA

Mappanyompa. (2019). Pengaruh Pendidikan Kemuhammadiyahan Terhadap Sikap Perilaku Siswa, Ibtida'iy Journal PGMI, 4 (1),17-29.

Sulistyaningsih Wiwik. 2008. Full Day School dan Optimalisasi Perkembangan Anak. Yogyakarta: Azzagrafika

Tafsir Ahmad. 2011. Ilmu Pendidikan dalam Perspektif Islam. Bandung: PT REMAJA ROSDAKARYA

Tohrin. 2012. Metode Penelitian Kualitatif dalam Pendidikan dan Bimbingan Konseling: Depok: PT RAJAGRAFINDO

Wiyani Novan Ardy. 2012. Sejarah Pendidikan Islam. Jakarta: Bumi Aksara

http:/elkawaqi.blogspot.com/2012/12/penge rtian-implementasi-menurut para.html

https://silabus.org/full-day-school/ 